
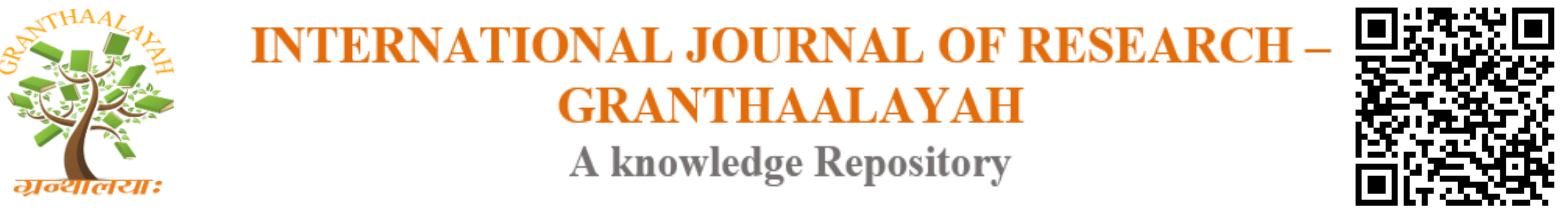

Science

\title{
OVERCOMING ABIOTIC SHADES FOR SWEETPOTATO (IPOMOEA BATATAS L.) IN THE HIGHLAND OF PAPUA, INDONESIA: THE ADAPTATION OF VARIETIES AND STICKS INCLINATION ANGLES
}

\author{
Alberth Soplanit ${ }^{* 1}$, Bambang Guritno ${ }^{2}$, Ariffin ${ }^{2}$, Nur Edy Suminarti ${ }^{2}$ \\ ${ }^{1}$ Graduate School of Agriculture, Faculty of Agriculture, Brawijaya University, Malang, \\ Indonesia / Papua Assessment Institute for Agricultural Technology, Indonesia \\ ${ }^{2}$ Faculty of Agriculture, Brawijaya University, Malang, Indonesia
}

\begin{abstract}
Abiotic shades due to the high level of cloud are the major problem causing a low level of sweetpotato (Ipomoea batatas L.) photosynthesis in the higland of Papua, Indonesia. In order to optimize the growth and production of sweetpotato, it needs to engineer the growing environment for the crop. This study aims to learn the growth, production and photosynthesis efficiency $(\mathrm{E} \mu)$ by combining varieties and sticks inclination angles on $(1.560 \mathrm{~m}$ asl $)$ from April to September 2016. It was conducted using a Split-Plot Design with three replications. The main plot was three sweet potato varietes: Siate, Papua Salosa and Cangkuang, while the subplot was the inclination of sticks with three angles: $90^{\circ}, 60^{\circ}, 45^{\circ}$ and without using sticks. The result shows that a combination of Cangkuang and $90^{\circ}$ stick inclination produces the highest total dry matter and tubers (326.9 g/plant and $248.7 \mathrm{~g} /$ plant respectively). The highest net assimilation rate was obtained in combination of Cangkuang with stick inclination angles treatments $90^{\circ}$ and $60^{\circ}$ for $125.2 \mathrm{mg} . \mathrm{cm} 2$.day-1 and $105.3 \mathrm{mg} . \mathrm{cm} 2$.day-1, the leaf area index ranged from 0.9-5.5. The highest tubers yield was achieved by the Cangkuang with $90^{\circ}$ and $60^{\circ}$ sticks inclination angles treatments, which are 31.53 t.ha-1 and 28.86 t.ha-1 respectively, with the harvest indexes around $36-62 \%$, in which the tubers yield and the harvest indexes have significant correlations. The highest photosynthesis efficiency was achieved by the Cangkuang with $90^{\circ}(3.83 \%)$ and 600 (3.34\%) sticks inclination angles treatments, while the lowest one was done by the Siate and without sticks $(0.92 \%)$ treatment. As a conclusion, the higher sticks inclination angles applied on the sweetpotato varieties, particularly whose wider leafs, under abiotic shade conditions may increase crop growth rates, total and tuber dry matters, tubers yield, harvest indexes, and photosynthesis efficiency rates.
\end{abstract}

Keywords: Variety; the Use of Sticks; Abiotic Shades; Highland; Papua.

Cite This Article: Alberth Soplanit, Bambang Guritno, Ariffin, and Nur Edy Suminarti. (2017). "OVERCOMING ABIOTIC SHADES FOR SWEETPOTATO (IPOMOEA BATATAS L.) IN THE HIGHLAND OF PAPUA, INDONESIA: THE ADAPTATION OF VARIETIES AND STICKS INCLINATION ANGLES.” International Journal of Research - Granthaalayah, 5(11), 379-389. https://doi.org/10.29121/granthaalayah.v5.111.2017.2371. 


\section{Introduction}

The Baliem valley has an area of $960 \mathrm{Km}^{2}$, located in the Jayawijaya Regency of Papua, with an elevation of $1560 \mathrm{~m}$ asl. This region is unique as it has a vast variey of bio-diversity which has strongly attached to the socio-culture of indigenous people since hundred years ago. According to de Fretes et al. (1999) and Kogoya et al. (2014), Papua has the highest endemic species in the world. Meanwhile, Arobaya and Pattiselanno (2007) indicate there are 35 uselful crops used by the Dani people who live in the Baliem valley for many purposes, in which Pandanus and Sweetpotato are the most well-known crops. Sweetpotato is staple food for people, feed for livestock, and widely used for traditional ceremonies (Wydiastuti, 1994). The Dani call it as hipere, regarded as a mother or woman crop which has 200 different cultivars cultivated in the Baliem valley and the other 400 ones grown around the valley (La Achmady et al., 1993; Rauf et al., 2009).

Soenarto (1997); Saraswati et al. (2013) mention that sun intensity radiation in the Baliem valley is only $1.38 \mathrm{~kJ} . \mathrm{cm}^{-2} . \mathrm{d}^{-1}$ with an average duration of sunlight around 3.98 hours/day and mostly cloudly. As a result, sunlight reached to soil surface and crops for photosynthesis becomes limited. To overcome the limitation of sun radiation intensity, the Dani adopts local knowledge in which they grow long-vine cultivars which are creeped to sticks whose $120-150 \mathrm{~cm}$ in height aiming to prevent leaves from shading one to the others, while short-vine ones are grew in the edge of gardens (Widyastuti, 1994). This practice aims to enable crop leafes get enough sunlight for photosynthesis and the crops produce big tubers. Johnston and Onwueme (1998); Onwueme and Johnston (2000) report that sweetpotato is the most intolerant tropical root crop to shade in which the higher shade rates the lower dry weight produce. Osvald, Alkaumper and Midmore (1994); Osvald, Alkaumper and Midmore (1995) also report that shade is responsible for the decrease of forming initiation, numbers, and sizes of tubers.

The Indigenous knowledge of Dani people as sweetpotato farmers in the highland of Papua has widely been studied by a number of scientists, e.g. Widyastuti, 1994; Soenarto, 1997 and Saraswati et al (2013). However, most of the studies only looked at the socio-cultural aspects, some did the agronomic ones, and none study the effect of abiotic shade due to cloudly high rates on the physiologi of sweetpotato crops. For the crops to be efficient in utilizing sun radiation and more photosynthesis results be stored in tubers, it needs environmental engineering by choosing appropriate varieties and the inclination of sticks to increase the interception and absortion of sun radiation by leafs.

According to Wargiono (1980), sweetpotato varieties whose wide leafs can have more effective photosynthesis processes and produce higher tubers compared to those whose narrow and fingering ones. Maryasa (1990) mentions that the use of sticks enables crops to catch sunlight efficently and reduces shade rates. Applying different inclination angles of sticks will change the position of leafs which can affect the absortion rate of sun energy by crops. This application follows the law of Lambert in Arifin (1987) which states that the absortion rate of sun energy by any surfaces is greatly affected by the edge of incoming sunlight.

This study aims to examine the capability of varieties with leafs morphology and different inclination angles of sticks to increase the efficiency of crops in utilizing sun radiation. The increase rate of efficiency in utilizing sun radiation by crops during their growing period can be 
measured through produce, dry weight characteristics, harvest indexes, and photosynthesis efficiency rates.

\section{Materiasl and methods}

\subsection{Sampling}

Fieldwork was conducted at Wesakin, Wouma District, Jayawijaya Regency, Papua, Indonesia $\left(138^{\circ} .57^{\prime} \mathrm{BT}, 04^{\circ}\right.$ 04' $\mathrm{LS}, 1550 \mathrm{~m}$ asl) during a planting season from April to September 2016. Trialing sweetpotato crops were grown on dryland with Typic Endoaquepts soil which has sandy loam texture and $\mathrm{pH}$ of 5.2. This trial used three sweetpotato varieties: Siate (local), Papua Sollosa (prime) and Cangkuang (prime). Tools involved roll-meter, digital scale, oven Memmert (21037 FNR type), Lightmeter LX 1330 B, digital thermometer, soil thermometer, soil moisture tester, cool box, tissue, cloth tarp, sack, shovel, sword, knife, $3 \mathrm{~mm}$ plastic rope, wooden stick, plastic sheet, label paper, brown envelope, rules, protactor, and stationary.

\subsection{Experimental Designs, Treatments, and Data Collection}

The experiment was conducted using a random spli-plot design with three replications. Sweetpotato variety is the main plot with three of type: Siate (V1), Papua Sollosa (V2) and Cangkuang (V3). Four different inclination angels of sticks are the sub plot: Without stick (A0), and sticks inclination of $45^{\circ}$ (A1), $60^{\circ}$ (A2), and $90^{\circ}$ (A3). The land for the experiment was traditionaly prepared using local shovel, and plots were divided into three group which each has 3 sub-groups with a size of $5.25 \mathrm{~m}$ x $6.50 \mathrm{~m}$. The distance between groups was $100 \mathrm{~cm}$, while the distance between sub-groups was $50 \mathrm{~cm}$. The planting space was 75 x $50 \mathrm{~cm}$ with only one cutting per planting hole in a single planting row. The weeding was done on 15, 45 and 80 Days After Planting (DAP). Both chemical ferilizer and pest-diseases control were not applied in this experiment following the local government prohibitation regulation. The observation was conducted using a destrucive method by taking 2 non-edge plants as samples on 40, 70, 100 and 130 DAP. These samples were taken using a local wooden stick called sege in the local languange. Sun radiation interception was measured on and under the leaf canopy using a lux meter LX 1330 B. The measurement was done three times on and under the leaf canopy, and also three times on the surface of soil at 11.00 AM when the wheater was bright. Global sun radiation data was also collected from a local meteorological station (Class III Wamena).

\subsection{Crop Measurement}

The observation variables included Leaf Area Index (LAI), Crop Growth Rate (CGR), Net Assimilation Rate (NAR), dry weight, tuber produce, Harvet Index (HI) and Photosynthesis Efficiency $(\mathrm{E} \mu)$. The leaf wide was measured using the Puch method (Etje and Osiru,1988), while the LAI, CGR and NAR were done using the Gardner et al. (1985) method, and the E $\mu$ was measured using the Yoshida (1981) method. The LAI was calculated from the area of leafs per land area. The CGR was done by the sum of total dry weight of crops per land area and per the age of crops. The NAR was done by the sum of of total dry weight of crops per leaf area unit and per the age of crops. The crop was separated into roots, stakes, leafs, dan tubers which were dried until the weight is constant in the oven with a temperature of $80^{\circ} \mathrm{C}$. The HI was defined as 
total tubers dry weight tubers divided by total crops dry weigth. Finaly, the E $\mu$ was measured basing on total crops dry weight $\left(\mathrm{gm}^{-2}\right)$ divided by cumulative sun radiation $\left(\mathrm{cal}^{-} \mathrm{cm}^{-2} \mathrm{day}^{-1}\right)$ after harvest.

\subsection{Statistical Analysis}

Statistical analysis was conducted using Analysis of Variance (ANOVA) with a different significancy level of 5\%. The difference between treatments was tested by Duncan Multiple Range Test (DMRT 5\%). The overall data compilation and analysis were processed using the GenStat 17 statistical program and Microsoft Office Excel 2010.

\section{Results and Discussion}

Table 1: Background of sweet potato variety used in the present study

\begin{tabular}{llll}
\hline \multicolumn{1}{c}{ Variety } & Stem length & Leaf color & Leaf form \\
\hline Siate & $150-250$ & Green & Triangular \\
Papua Sollosa & $120-150$ & Green & Cordate \\
Cangkuang & $120-150$ & Green & \\
\hline
\end{tabular}

\subsection{Leaf Are Index (LAI)}

In the early stage of vegetative periods, there is no significant difference in Leaf Area Index. However, at 70 - 130 DAP, the LAI begin to show significant differences $(\mathrm{p}<0.05)$ in between all of the treatment combinations. Changes in the LAI for the combination of varieties and sticks inclination angels according to crop growing periods are shown in Figure 1. After planting, the LAI increase fastly in line with crop growing periods reaching the peak at 100 DAP, then begin to fall approaching crop harvesting periods at 130 DAP. The highest LAI is achieved by the V3A2 (5.5) combination, while the optimum ones is done by the V3A3 (4.2) one, however is not significantly different from V3A2 (4.1). The difference in morphology causes the difference in physiological functions. Cangkuang whose has wide leafs compared to Siate and Papua Salosa whose have narrower leafs affects its LWIs. Physiologically, LAI and crop header architecture are important as they determine the capability of crops to absorb sunlight. The higher LAI the more sunlight can be caught by leafs. Brown (1992) estimates an LAI of $3-4$ is required to intercept $95 \%$ of PAR radiation in sweetpotato crops. Polynomial models to predict the highest and lowest LAI for the combination of varieties and sticks inclination angels are presented using the following equations: $y=-0.0002 x^{2}+0.0516 x-0.6504, R^{2}=0.9258$ (V1) (Figure 1a); V2y $=-0.0006 x^{2}+0.1253 x-3.3009, R=0.9247(V 2)\left(\right.$ Figure 1b) dan V3y $=-0.001 x^{2}+0.2044 x-$ 5.7005, $\mathrm{R}=0.9921$ (V3) (Figure 1c). 

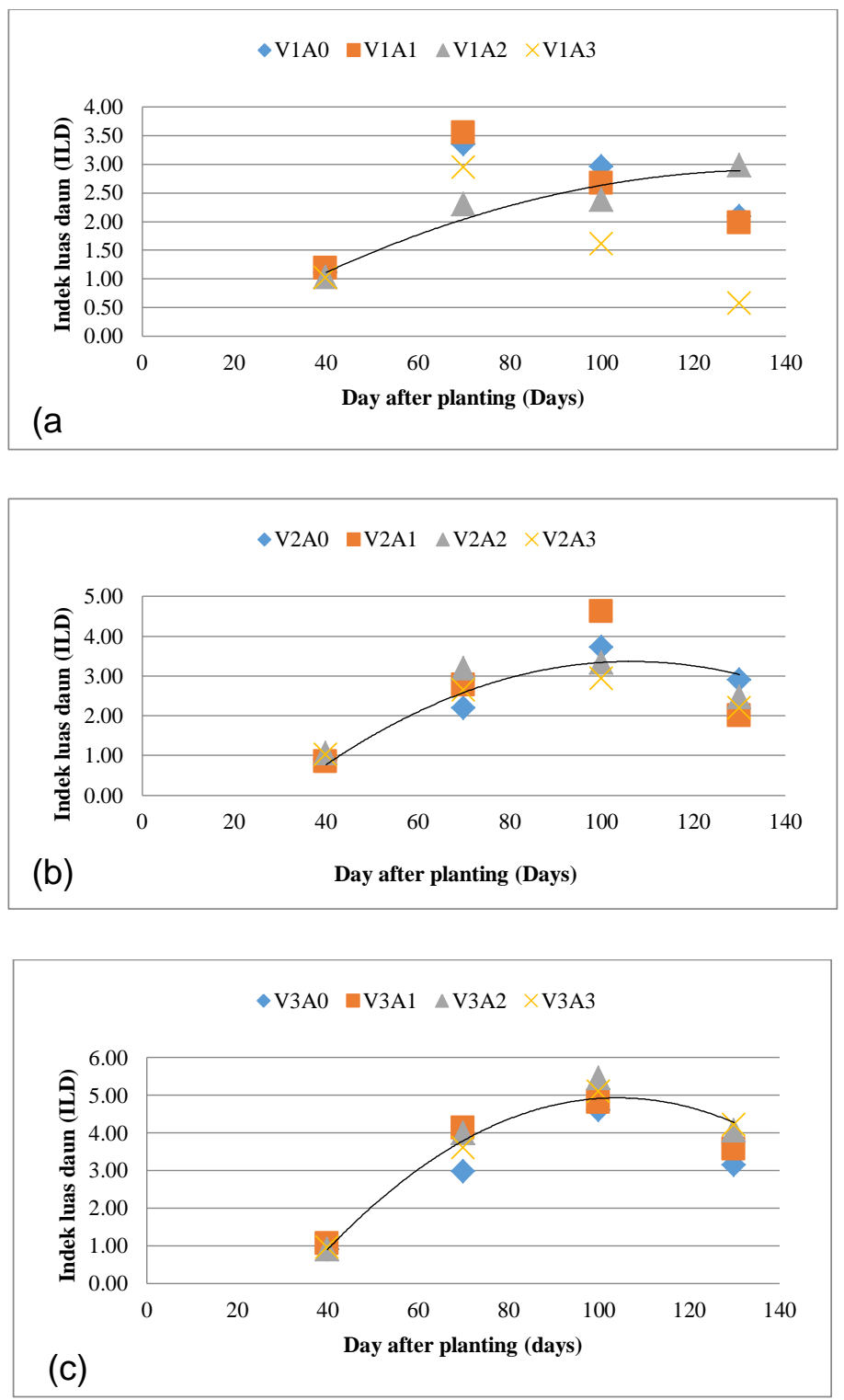

Figure 1: Correlations in between the combination of varieties and sticks inclination angels with LAIs for Siate (a), Papua Sollosa (b) dan Cangkuang (c). Their respective polynomial models are $\mathrm{V} 1 \mathrm{y}=-0.0002 \mathrm{x}^{2}+0.0516 \mathrm{x}-0.6504, \mathrm{R}^{2}=0.9258 ; \mathrm{V} 2 \mathrm{y}=-0.0006 \mathrm{x}^{2}+0.1253 \mathrm{x}-3.3009, \mathrm{R}^{2}=$ 0.9247 dan $V 3 y=-0.001 x^{2}+0.2044 x-5.7005, R=0.9921$.

\subsection{Crop Growth Rate (CGR) and Net Assimilation Rate (NAR)}

The effect of the combination of varieties and sticks inclination angels on Crop Growth Rates is presented at Figure 2a. It shows significant differences $(\mathrm{P}<0.05)$ from early growing to harvesting periods. The V3A3 treatment combination achieves the highest CGRs at 130 DAP (11.1 g.m ${ }^{2} \cdot$ day $\left.^{-1}\right)$. The CGRs increase until the medium stage of growing periods and begin to fall approaching the stage of harvesting periods. It confirms what Agatha (1982) has previously found out from her study. Cangkuang and Papua Sallosa tend to have higher CGRs than Siate. The increase of CGRs has a similar pattern to the increase of LAI. At 130 DAP, the CGRs reaches a maximum rate, while the LAI does an optimum one. Brown (1992) reports that a LAI 
of $3-4$ is achieved at $56-112$ DAP, in which the CGRs does a maximum rate which produces dry weight of $106-133 \mathrm{~g} . \mathrm{m}^{2}$.

Net Assimilation Rates (NARs) are net assimilation results per leaf wide unit and time. The NARs are significantly differences $(\mathrm{p}<0.05)$ among all the combination of varieties and sticks inclination angels from the early stage of growing to harvesting periods. The CGRs tend to be higher at vegetative phases, then fall gradually following the age of crops until generative ones. It is similar to Gardner (1991) that the CGRs are not constant and tend to fall following the age of crops as the older crops the more photosynthesis results are utilized to form tubers. At the early stage of growing periods, the V3A3 dan V3A2 combinations produce the highest NARs (125.2 mg.cm ${ }^{2}$.day ${ }^{-1}$ dan $105.3 \mathrm{mg} . \mathrm{cm}^{2}$.day ${ }^{-1}$ respectively; Figure $2 \mathrm{~b}$ ). This finding is higher than Kuhlase, L.M, et al (2009) in Swaziland at an elevation of $732 \mathrm{~m}$ asl and Widaryanto and Saitama (2017) in Malang, Indonesia at $303 \mathrm{~m}$ asl. Putting all the findings together indicates that NARs vary from lowland to highland. Hozyo et al. (1982) mentions that maximum NARs affected by elevation are $40-50 \mathrm{~g} / \mathrm{m}^{2} /$ week at lowland and $50-70 \mathrm{~g} / \mathrm{m}^{2} /$ week at highland. Low temperature at highland causes smaller photosyntate used for respiration compared to lowland.

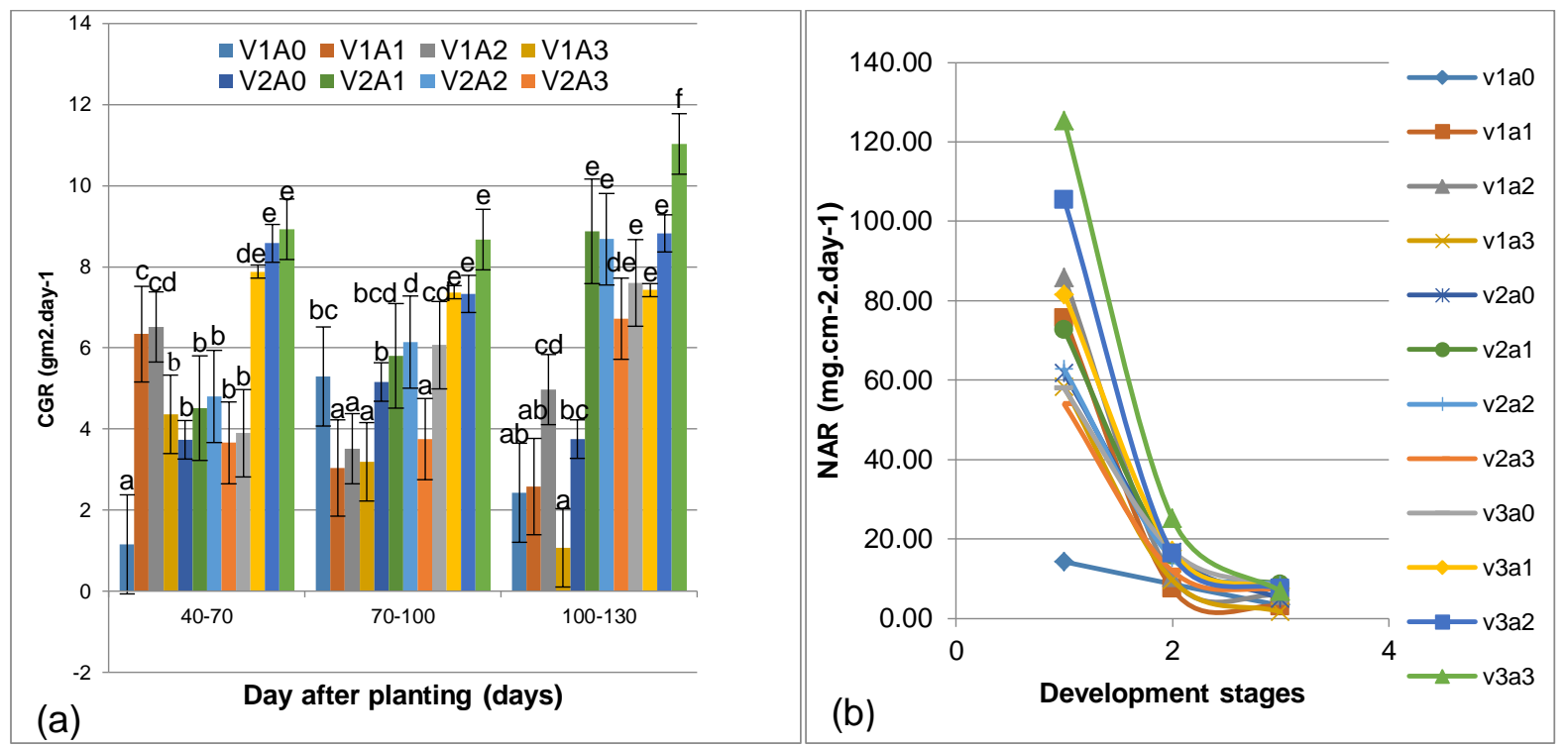

Figure 2: The effect of the combination of varieties and sticks inclination angles on CGRs (a) and NARs (b)

\subsection{Tuberous Root Dry Weight (TW) and Total Dry Weight (TDW)}

The results show that Tuberous Root Dry Weight (TWs) increase following the age of crops. The increase of sticks inclination angels at all the varieties increases the TWs, except Siate and Papua Sallosa at $90^{\circ}$ stick angle. The combination of varieties and sticks inclination angels does not affect the TWs at vegetative periods (40 DAP), and started to affect significantly $(\mathrm{P}<0.05)$ at generative periods until harvesting time $(70-130 \mathrm{DAP})$. This finding may indicate that the formation of tubers is started at $70 \mathrm{DAP}$ and continued linearly until harvesting periods. The V3A4 combination achieves the highest TWs at 130 DAP (248.7 g/plant). This finding is lower than Bhagsari and Doyle A. Ashley (1990) in Fort Valley State College which studied 15 sweetpotato genotypes at 122 DAP. Corelations between the TWs and TDWs are significant 
correlations, in which the increase of TDWs is affected by the increase of TWs. The equation is $y=1.2434 x+45.176, R^{2}=0.8951$, correlation coefficient, $r=0.9460$ (Figure 3a).

The combination of varieties and sticks inclination angels affects TDWs significantly $(\mathrm{P}<0.05)$ at all stages of growing periods, except vegetative ones at 40 DAP. The highest TDWs are achieved by the V3A3 combination at 130 DAP (326.9 g/plant). In the field, the development of crops depends on the capacity of canopies to intercept radiation and change it becoming new biomass (Gifford et al.b1984; Adeboye et al. 2016). this interception is affected by LAIs, while the capony orientation for Photosynthesis Active Radiation (PAR) is influenced by LAIs and the order of leafs (Plenet et al., 2000).
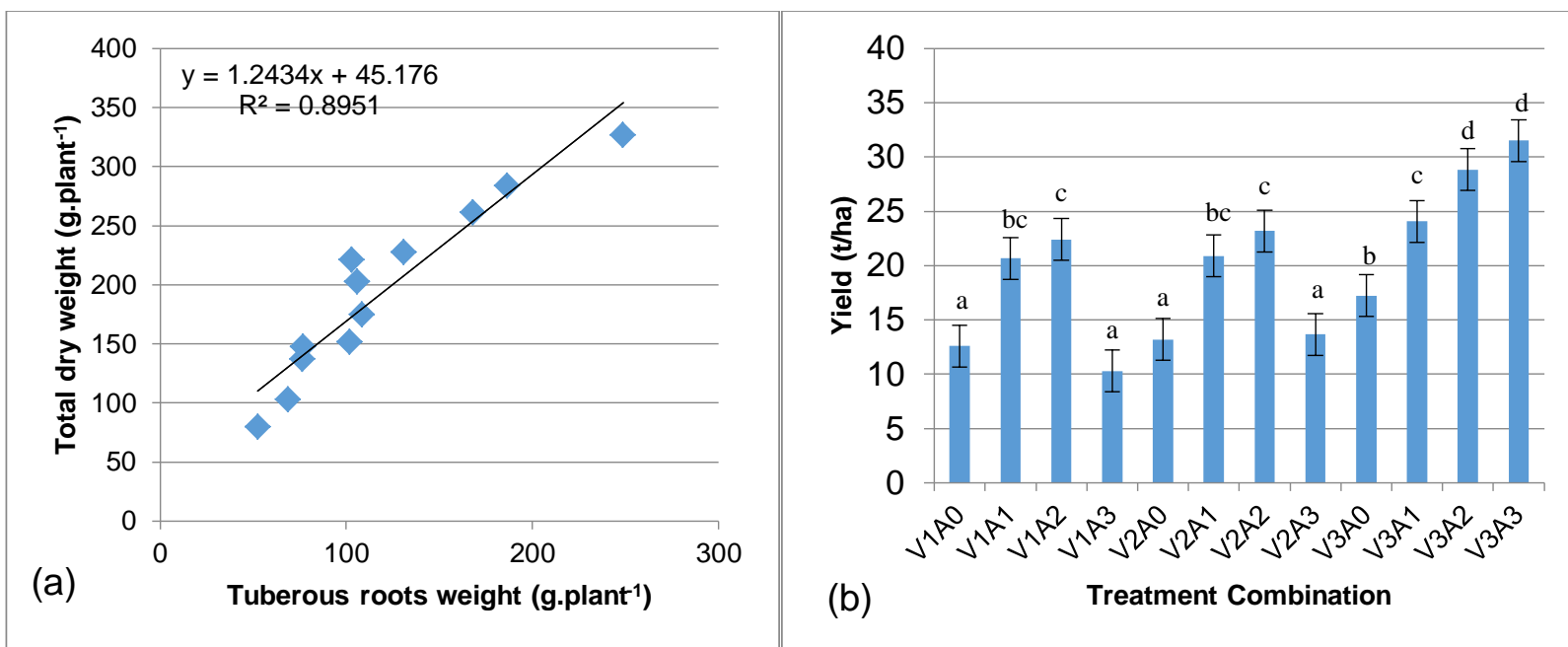

Figure 3: Correlations between TWs and TDWs (a) and sweetpotato production from all the combination of varieties and sticks inclination angels $(\mathrm{P}<0.05)(\mathrm{b})$.

\subsection{Tuber Yield (TY) and Harvest Index (HI)}

The treatments combination of varieties and sticks inclination angels shows significant differences in TY $(\mathrm{P}<0.05)$ ranging from $12.60 \mathrm{t} / \mathrm{ha}$ to $31.53 \mathrm{t} / \mathrm{ha}$ (Figure $3 \mathrm{~b})$. The V3A3 and V3A2 treatments achieve the highest TY (31.53 t/ha and $28.86 \mathrm{t} /$ ha respectively), while the V1A0, V1A3, V2A0 and V2A3 treatments do the lowest ones. The treatments combination of varieties, whose wider leaf in particular, and higher sticks inclination angles locates the position of leafs more vertical, in which in a low sunlight condition enables the leafs to catch more sunlight for photosynthesis. In contrast, the treatments combination of varieties and without sticks causes only leafs on the top catching more sunlight, while the below ones doing less as they are shaded which also mean less photosynthesis. In addition, the low TY on the Siate and Papua Sollosa with the sticks inclination angle of $90^{\circ}$ treatments is also due to some leafs become dry and fall.

Translocation efficiency to the economic of TYs defines HI, which is a biological weight proportion unit transformed to yields. The ANOVA of HI at 150 DAP is presented at Figure 4a. The treatments combination of varieties and sticks inclination angles have significant differences $(\mathrm{p}<0.05)$ in HIs ranging from $36 \%$ to $62 \%$. The highest HIs is achieved by the V1A1-V1A3 treatments, however they are not sigificantly different from the V2A1-V2A3 and V1A1-V1A2 
treatments. This finding means the use of sticks for all the varieties may increase HIs, except Siate with the sticks inclination angle of $90^{\circ}$ due to many senescence leafs. The higher HIs the more efficient for the crop to utilize photosynthesis results for the formation of tubers. It explains that the higher position of leafs or the more vertical order of leafs facing incoming-sunlight, the more sunlight being distributed into all leafs in every canopy layer, which means the more efficient for the crop to utilize sunlight. Wigham and Wooley (1974) state that the orientation of leafs affects the radiation interception of sunlight by header crops, in other words, a vertical header crop is more efficient to intercept sunlight radiation than a horizontal one. Moreover, Wang et al. (2014) state that low interception efficiency due to shade reduces TY and dry matter accumulation significantly, however it increases shoot/root ratios. The TYs has strong correlations with the HIs as they show in the following linier equation: $y=69.663 \mathrm{x}-17.15, \mathrm{R}^{2}=$ 0.7164, coefficient correlation, $r=0.8464$ (Figure 4b). This finding similar to Bhagsari (1990) who concludes that both fresh and dry sweetpotato TYs have significant correlations with HIs.

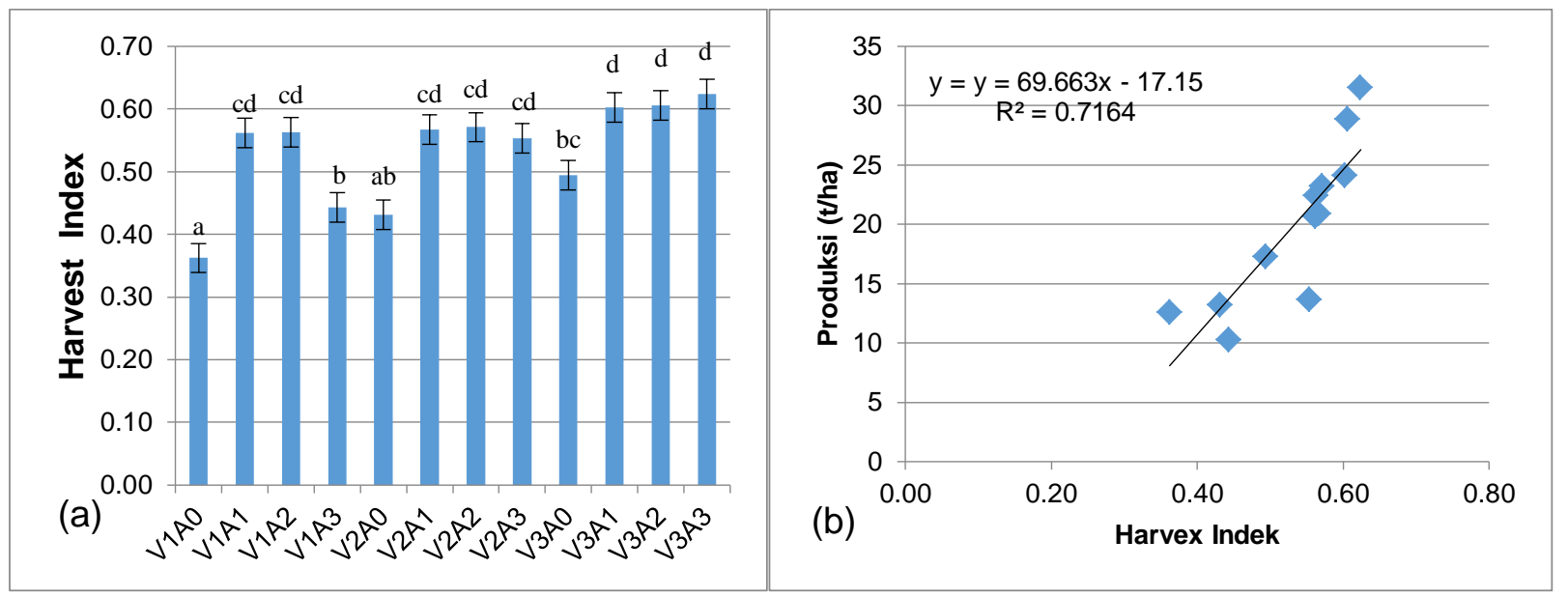

Figure 4: HIs for all the treatments combination of varieties and sticks inclination angels $(\mathrm{p}<0.05)(\mathrm{a})$ and correlations between TYs and HIs (b).
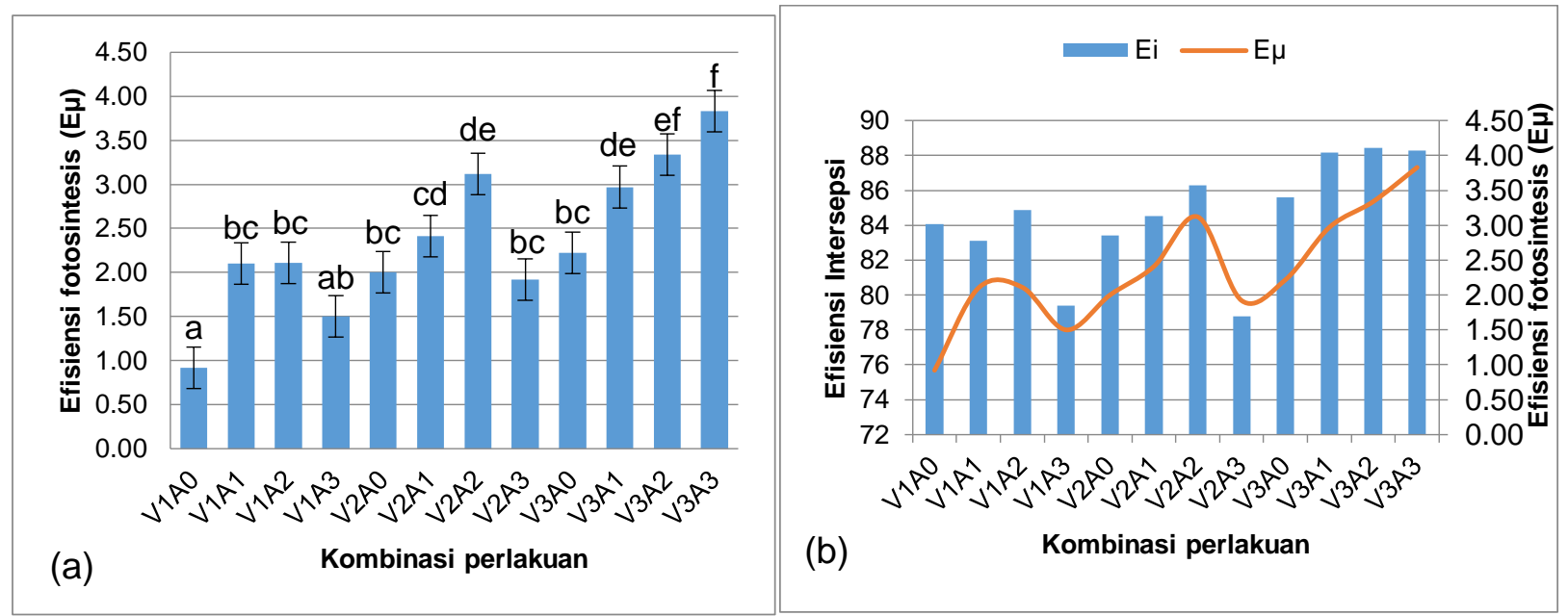

Gambar 5: Photosynthesis efficiency (E $\mu$ s) for the treatments combination of varieties and sticks inclination angels DMRT $(\mathrm{P}<0.05)(\mathrm{a})$ and correlations between the interception efficiency and

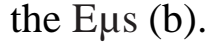




\subsection{Photosynthesis Efficiency $(\mathrm{E} \mu)$}

$\mathrm{E} \mu$ is a comparison between energy needed for crops to produce chemical energy or organic materials and total energy received by the crops (Yoshida, 1981; Sitaniapessy, 1985). The ANOVA for the E $\mu \mathrm{s}$ in this study is presented at Figure 5a. The average E $\mu$ s for the treatments combination of varieties and sticks inclination angels show significant differences $(\mathrm{p}<0.05)$ ranging from 0.92 to $3.83 \%$. The $\mathrm{V} 3 \mathrm{~A} 3$ and $\mathrm{V} 3 \mathrm{~A} 2$ treatments show the highest E $\mu \mathrm{s}$ (3.83 and $3.34 \%)$, while the V1A0 treatment does the lowest one $(0.92 \%)$. This finding is considered to be high as E $\mu$ s for sweetpotato crops, according to Rana and Rana (2014) is generally only 1.6 $1.9 \%$. The correlations between the interception efficiency and the Eus are shown at Figure $5 \mathrm{~b}$. The interception efficiency increases in all the treatments, except the V1A3 and V2A3 ones due to its leaf morphological characteristics (narrower and fingery) causing even at the sticks inclination angle of $90^{\circ}$, still much radiation escape from leafs catching. This finding means that the varieties whose wider leafs and more vertical of orientation leafs order treatments can increase their E $\mu \mathrm{s}$ due to higher PARs intercepted by each leaf in every header layers. Goudriaan (2016) states that the distribution of leafs plays an important role in determining sunlight interception. If water and nutrients supply is sufficient, the use efficiency of sunlight radiation by crop-headers will be determined by the interception of sunlight by crop-headers and the distribution pattern of sunlight in crop-headers (Monteith, 1977; Sitaniapessy, 1985). Govindjee and Thomas D. Sharkey (2016) conclude that if LAIs are high, photosynthesis canopy will be maximized by the vertical inclination of leafs.

\section{Conclusions}

Tubers and total dry weights increase on all the sweetpotato varieties following the higher inclination angles of sticks, except on the combination of Siate and Papua Salosa varieties with the inclination angle of sticks of $90^{\circ}$. The major factor which affects the dry weight produce was the leaf wide index. The crops growth rates increase from vegetative to early genarative periods in which the highest (11.1 g.plant ${ }^{-2}$ ) was achived by the combination of Cangkuang variety and the inclination angle of stick of $90^{\circ}$, on 100 DAP, following the increase pattern of leafs area index. The crops growth rates on the combination of Papua Salosa and Cangkuang varieties with sticks tend to be higher compared to the combination of Siate variety with sticks, except during the early growing period. The components related to the economic result of sweetpotato are tubers produce and harvest index. Cangkuang variety whose wide leafs morphology achives the highest produce when it combines with the inclination angles of sticks of $90^{\circ}$ and $60^{\circ}\left(31.53\right.$ t.ha $^{-}$ ${ }^{1}$ and 28.86 t.ha $^{-1}$ respectively). The harvest indexes increase following the increase inclination angles of sticks on all the varieties, except Siate. Finally, the photosynthesis effciency rates also increase in line with the increase efficiency of interception in which the highest is achieved by the combination of Cangkuang variety and the inclination angles of sticks of $90^{\circ}$ and $60^{\circ}(3.83 \%$ and $3.34 \%$ respectively).

\section{Acknowledgement}

This study was financially supported by the Indonesian Agricultre Research and Development Institute. My appreciation also goes to the ACIAR/SARDI/CIP/BPTP Papua project which was also provided some financial supports. 


\section{References}

[1] Agata, W. 1982. The characteristics of dry matter and yield production in sweet potato under field conditions. P.119-127. In R.L. Villareal and T.D. griggs (ed.). Proc. $1^{\text {st }}$ int. Symp.Sweet Potato. AVEDC, Taiwan.

[2] Arifin. 1987. Dasar - dasar Agroklimatologi. Fakultas Pertanian, Universitas Brawijaya, Malang. 110 hal.

[3] Arobaya, A.Y.S. dan F. Pattiselanno (2007).Jenis Tanaman Berguna Bagi Suku Dani di Lembah Baliem.Komunikasi pendek.

[4] Adeboye. O.B, Bart Schultz, Kenneth O. Adekaluand Krishna Prasad (2016). Impact of water stress on radiation interception and radiation use efficiency of Soybeans (Glycine max L. Merr.) in Nigeria. Braz J Sci Technol (2016) 3:15.

[5] Baghasri, A.S. and Doyle, .A.Ashley (1990). Relationship of photosynthesis and harvest index to sweet potato yield.Journal of American Society of Horticultural Science 115 (2):288-293.

[6] Brown, R.H. (1992). Photosynthesis and Plant Productivity. In. Hill WA, Bonsi CK, Loretan PA (eds) Sweet Potato Technology for the $21^{\text {st }}$ Century, Tuskegee University, Tuskegee, AL, pp 273281.

[7] C. Onwueme And M. Johnston (2000). Influence Of Shade On Stomatal Density, Leaf Size And Other Leaf Characteristics In The Major Tropical Root Crops, Tannia, Sweet Potato, Yam, Cassava And Taro. Exp Agric 36(4):509-516.

[8] de Fretes, Y., Yaap, B., Mack, A. and Allen, G., 1999, Mengenal Keanekaragaman Hayati Irian Jaya,Conservation International Indonesia, Jakarta.

[9] Gifford RM, Thorne JH, Hitz WD, Giaquinta RT (1984). Crop productivity and photoassimilate partitioning. Science 225:801-808.

[10] Gardner, F.P., R.B. Pearce, dan R.L. Mitchell. 1991. Physiology of Crop Plants (diterjemahkan dari: Fisiologi Tanaman Budidaya, penerjemah: HerawatiSusilo). Penerbit Universitas Indonesia. Jakarta. 428 hal.

[11] Goudriaan J (2016) Light distribution. In: Hikosaka K,Niinemets Anten N (eds) Canopy Photosynthesis: From Basics to Applications. Springer, Berlin, pp 3-22.

[12] Govindjee and Thomas D. Sharkey (2016). Advances in Photosynthesis and Respiration Including Bioenergy and Related Processes: Volume 42: Canopy Photosynthesis: From Basics to Applications. From the Series Editors: 364-377.

[13] Hozyo, Y. 1982. Photosynthetic activity and carbon dioxide diffusion resistance as factors in plant production in sweet potato plants. In: R.L. Villarel and T.D. Griggs (eds.), Sweet Potato Proc. J 81 Int. Symp. A VRDC, Taiwan, China. pp. 129-133.

[14] Johnston M, Onwume I.C (1998). Effect of shade on photosynthetic pigments in the tropical root crops: yam, taro, tannia, cassava and sweet potato. Exp Agric 34 (3):301-312.

[15] La Achmady and J. Schneider. 1993. Sweet potato germplasm in Jayawijaya division of Irian Jaya diversity, problems, and pathways for conservation. Workshop on Farm Conservation, 6-8 December, International Potato Center-ESEAP-Central Research Institute for Food Crops, BogorIndonesia.

[16] Monteith, J.L. (1977).Climate and Efficiency of Crop Production in Britain. Philosophical Transactions of the Royal Society London B, 281, 277-294.

[17] Maryasa, A. 1990.Pengaruh tinggi lanjaran dan waktu pemetikan sebagianpolong muda terhadap produksi dan viabilitas benih kacang panjang(Vigna sinensis (L.))Savi ex Hassk).Skripsi. Jurusan Budidaya Pertanian,Faperta, IPB. Bogor. 63 hal.

[18] Etje, O.T and D.S.E. Osiru, 1988. Methods for determining leaf area in some crop plants. Casavabased Cropping Systems Research I. Contributions from the First Annual Meeting of the Collaborative Group in Cassava-based Cropping Systems Research. International Institute of Tropical Agriculture, Ibadan, Nigeria. 16-19 November 1987. 
[19] Oswald A, J.Alkamperand D.J. Midmore (1994). The effect of different shade levels on growth and tuber yield of sweet potato. II. Plant Development. J Agron Crop Sci 173 (1): 41-52.

[20] Oswald A, J. Alkamper and D.J. Midmore (1995). The effect of different shade levels on growth and tuber yield of sweet potato. II. Tuber yield. J Agron Crop Sci 175 (1):29-40.

[21] Ossom, E.M., L.M.Kuhlase and R.L.Rhykerd (2009).Effect of plant population on Yield Components and yield on Intercropedd Sweet Potato [Ipomoea batatas (L.) Lam.] And Groundnud (Arachis hipogaea L.). America-Eurasian, Journal of Agronomy 2 (1): $\quad 01-06$.

[22] Plenet, D. A. Mollier, S. Pellerin (2000). Growth analysis of maize field crops under phosphorus deficiency. II. Radiation-use efficiency, biomass accumulation and yield components. Plant Soil 224: 259-272.

[23] Rauf, A.W. dan M.S.Lestari. 2009. Pemanfaatan komoditas pangan lokal sebagai sumber pangan alternatif di Papua. Jurnal Litbang Pertanian, 28 (2):54-62.

[24] Rana, S.S. dan R.S. Rana. 2014. Advances in crop growth and productivity. Department of Agronomy, CSK HP Krishi Vishvavidyalaya, Palampur, India.

[25] Sitaniapessy PM. 1985. Pengaruh jarak tanam dan besarnya populasi tanaman terhadap absorbsi radiasi surya dan produksi tanaman jagung (Zea mays L.) [disertasi]. Bogor: Institut Pertanian Bogor.

[26] Soenarto, 1987.Wen Hipere suatu sistem budidaya ubijalar (Ipomoea batatas (L) (Lam) di Lembah Baliem, Irian Jaya.Institut pertanian Bogor. Fakultas Pascasarjana, Bogor. (tidak dipublikasikan).

[27] Sugito, Y., 2013. Research Methods: Experiment Method and Scientific Writing. UB Press, Universities Brawijaya, Malang.

[28] Saraswati, P., A. Soplanit., A.T. Syahputra, L. Kossay, N. Muid, E. Ginting and G.Lyons. 2013. Yield trial and sensory evaluation of sweetpotato cultivars in Highland Papua and West Papua Indonesia. Journal of Tropical Agriculture 51 (1-2): 74-83.

[29] Wigham, D.K .and D.Wooley, 1974. Efect of Leaf Orientation. Leaf Area and Plant Densities on Corn Production. J. Agron. 66: 482-486.

[30] Wargiono, J. 1980. Ubijalar dan cara bercocok tanamnya. LPP. Bul. Tek. No.5. 37 hal.

[31] Widyastuti, C.A. 1994. Peranan wanita suku dani dalam mempertahankan kelangsungan ubijalar sebagai makanan pokok di Kabupaten Jayawijaya, Irian Jaya.Dalamrisalah seminar penerapan teknologi produksi dan pasca panen ubijalar mendukung agro-industri.Edisi Khusus Balai Penelitian Tanaman Pangan Malang (3): 353-360.

[32] Wang Q, Hou F, Dong S, Xie B, Li A, Zhang H, Zhang L (2014) Effects of shading on the photosynthetic capacity, endogenous hormones, and root yield in purplefleshed sweet potato (Ipomoea batatas (L.) Lam). Plant Growth Regul 72:113-122.

[33] Widaryanto, E. and Akbar Saitama (2017). Analysis of Plant Growth of Ten Varieties of Sweet Potato (Ipomoea batatas L.) Cultivated in Rainy Season.Asian J. Plant Sci., 16 (4): 193-199.

[34] Yoshida, S. 1981. Fumandamentalis of Rice Crop Science. P.1-110. IRRI, Los Banos, Philipines.

*Corresponding author.

E-mail address: asoplanit@yahoo.co.id 